\title{
HUKUM ISLAM: SINERGISITAS TEKS, MORAL, DAN AKAL
}

\author{
Mohamad Ikrom \\ Jhoncenna123@yahoo.com \\ IAIN Jember
}

\begin{abstract}
ABSTRAK
Perkembangan paradigma ilmiah modern memiliki dampak yang signifikan terhadap perkembangan yurisprudensi. Salah satu contohnya adalah pengaruh postmodernisme yang telah menyebabkan pemikiran bahwa hukum tidak lagi dianggap hanya sebagai realitas sosial; sebaliknya, hukum juga merupakan realitas metafisik. Pergeseran paradigma yurisprudensi dari positivisme ke postmodernisme dianggap sejalan dengan pemikiran Islam tentang yurisprudensi. Hal ini dikarenakan, pertama, yurisprudensi Islam membutuhkan kombinasi pikiran dan hati; kedua, kekurangan bayani, epistemologi 'irfani dan burhani membutuhkan epistemologi par excellence, yaitu kombinasi mereka; ketiga, moralitas agama memainkan peran penting dalam membentuk tatanan sosial.
\end{abstract}

Kata kunci: moral, teks, akal, epistemologi,hukum Islam.

\begin{abstract}
The development of paradigm of modern scientific has a significant impact on the development of jurisprudence. A case in point is the influence of postmodernism which has led to a thought that law is no longer deemed as merely a social reality; instead, law is also a metaphysical reality. The shift of jurisprudence paradigm from positivism to postmodernism is considered in line with Islamic thoughts on jurisprudence. Because of, first, Islamic jurisprudence requires the combination of mind and heart; second, the shortcoming of bayani, 'irfani and burhani epistemology necessitates a par excellence epistemology i.e. their combination; third, religious morality plays an important role in forming a social order.0
\end{abstract}

Key words: moral, text, mind, epistemology, islamic law.

\section{PENDAHULUAN}

Dinamika atau perubahan pandangan dunia (worldview) merupakan suatu kenyataan yang tidak biasa dibantah dan telah menjadi sifat dasar dari segala yang ada di bumi, termasuk manusia dan lembaga-lembaga yang ia bangun. Semua lembaga, baik keagamaan, negara, maupun kemasyarakatan, tidak ada yang luput dari dinamika kehidupan ini. Bahkan, kelestarian lembaga itu sedikit banyaknya tergantung dan dipengaruhi oleh sejauh mana mereka dapat menyesuaikan diri dengan irama perubahan tersebut (Mulyadi Kartanegara, 2000: 245-267). Begitu juga, perkembangan paradigma keilmuan 
mempunyai pengaruh yang cukup signifikan dalam perkembangan disiplin ilmu, terutama disiplin ilmu hukum. Buktinya, aliran positivisme Auguste Comte (1798-1857) telah "memaksa" hukum sebagai sistem positivisme hukum analitik. Aliran hukum positivisme analitik ini dikembangkan oleh John Austin yang mengatakan bahwa materi hukum itu adalah hukum positif atau hukum yang ditetapkan oleh para politisi yang berkuasa terhadap rakyat sebagai hukum yang berlaku (Moh Mahfud, 1999: 40).

Sebaliknya, postmodernisme (postpositivisme) yang menekankan keterkaitan antara wilayah empirik dan moral, telah melahirkan pandangan bahwa hukum tidak dimaknai sebagai realitas sosial yang empirik an sich, tetapi hukum juga dimaknai sebagai realitas metafisik yang tidak dapat dijangkau oleh indera. Berdasarkan pemahaman ini, hukum dimaknai tidak saja sebagai fenomena sosial tetapi juga fenomena rohani (Costaz Douzinas. et. Al, 1991: 28). Pergeseran paradigma hukum dari orientasi legisme positivistik menuju orientasi postmodernis ini ditengarai sejalan dengan ranah pemikiran hukum Islam. Oleh karena itu, artikel ini mencoba membahas bangunan pemikiran hukum Islam yang memiliki titik temu dengan pandangan hukum sebagai fenomenan sosial dan fenomena rohani.

\section{PEMBAHASAN}

\section{Peta Epistemologi dalam Islam}

Ilmu pengetahuan yang merupakan kunci dari kemajuan yang diraih umat manusia, tentunya tidak bisa datang begitu saja tanpa adanya suatu proses sebelumnya. Proses untuk mendapatkan ilmu pengetahuan ini dalam kajian filsafat dikenal sebagai epistemologi. Bidang epistemologis ini menempati posisi yang sangat strategis, karena ia membicarakan tentang cara untuk mendapatkan pengetahuan yang benar. Mengetahui cara yang benar dalam mendapatkan ilmu pengetahuan berhubungan erat dengan hasil yang ingin dicapai. Pada akhirnya, kepiawaian dalam menentukan epistemologis, akan sangat berpengaruh pada warna atau jenis ilmu pengetahuan yang dihasilkan ( $R$. Harre, 1978: 5). Berdasarkan dua buah karya Muhammad 'Abid al-Jabiri (1991)-selanjutnya ditulis al-Jabiri(Takwin al-'Aql al-'Arabi dan Bunyah al-'Aql al-'Arabi: Dirasah Tahliliyah Naqdiyyah li Nuzhum al-Ma'rifah fi alTsaqafah al-Arabiyah) (Muhammad 'Abid al-Jabiri, 1993) dapat diketahui bahwa epsitemologi Islam menurutnya 
dapat dipetakan ke dalam tiga bagian; epistemologi bayani, epistemologi irfani, epistemologi burhani. Adapun pembahasan secara ringkas tentang ketiga epistemologiini adalah sebagai berikut.

\section{Epistemologi Bayani}

Secara etimologi, bayani mempunyai arti menyambung, memisahmisahkan, terang dan jelas, kefasihan dan kemampuan dalam menyampaikan, serta kekuatan untuk menerima dan menyampaikan kejelasan. Sedangkan secara terminologi, dengan mengutip pendapat al-Jahiz dalam kitabnya alBayan wa al-Tabyin, al-Jabiri mengartikannya sebagai nama universal (ism jami') bagi setiap pemahaman makna, sedangkan apabila merujuk kepada pendapat al-Syafi'i, bayani merupakan nama universal bagi maknamakna yang terdapat dalam kumpulan landasan pokok (al-ashl) dan mengurai cabang (al-furu') (Muhammad 'Abid al-Jabiri, 1993: 20). Munculnya tradisi bayani ini menurut al-Jabiri bukan suatu hal yang asal jadi. Akan tetapi memiliki akar historisnya dalam sejarah budaya dan tradisi pemikiran Arab. Aktivitas dan kelahiran bayani dimulai dengan apa yang disebut masa kodifikasi ('asr tadwin), yaitu masa berlangsungnya proyek konstruksi budaya secara massif dalam pengalaman sejarah peradaban Islam, yakni antara pertengahan abad ke$2 \mathrm{H}$ sampai pertengahan abad ke-3 $\mathrm{H}$. Pada perkembangannya, peradaban ini telah membentuk kerangka rujukan bagi pemikiran Arab dengan segenap disiplin keilmuan yang beragam (Muhammad 'Abid al-Jabiri, 2000:60). Menurut alJabiri, aktivitas nalar bayani terjadi dalam tiga hal; (1) aktivitas intelektual yang bertitik tolak dari ashl yang disebut dengan istinbat (penggalian pengetahuan dari teks), (2) aktivitas intelektual (altafkir) yang bermuara pada ashl yang disebut dengann qiyas, (3) aktivitas pemikiran dengan arahan dari ashl, yaitu dengan menggunakan metode al-istidlal al-bayani (Muhammad 'Abid al-Jabiri,, 1993). Dengan demikian, epistemologi bayani mempunyai ciri spesifik yaitu selalu berpijak pada ashl (pokok) yang berupa nas (teks).

Nalar 'irfani yang dikehendaki oleh al-Jabiri adalah nalar 'irfani dalam pengertian gnostik. Sehingga dari perspektif epistemologis, gnostik merupakan prinsip dasar, konsep, dan prosedur yang membangun dunia berfikir dalam peradaban Arab dengan dua porosnya; pertama, penggalian bahasa dengan menggunakan pasangan epistemologis makna eksoteris/esoteris 
yang sejajar dengan pasangan kata/makna dalam ternd akal retoris, dan kedua, mengabdi dan menggali manfaat dari politik secara bersamaan dengan menggunakan pasangan epistemologis kewalian/kenabian yang sejajar dengan pasangan epistemologis principium/ cabang dan pasangan substansial/ accidens dalam terend akal retoris.

\section{Epistemologi 'Irfani}

Kata 'irfan adalah bentuk masdar dari kata 'arafa yang berartin ma'rifah (ilmu pengetahuan) (Abied Shah, M. Aunul dan Sulaiman Mappiase, dalam M Aunul Abied Shah, ed, 2001: 317). Kemudian 'irfan lebih dikenal sebagai terminologi mistik yang secara khusus berarti "ma'rifah" dalam pengertian "pengetahuan tentang Tuhan" (Muhammad 'Abid al-Jabiri, 1993). Kalau ilmu (pengetahuan eksoterik) yakni pengetahuan yang diperoleh indera dan intelek melalui istidlal, nazhar, dan burhan, maka 'irfan (pengetahuan esoterik) yaitu pengetahuan yang diperoleh qalb melalui kasyf, ilham, i'iyan (persepsi langsung), dan isyraq.

\section{Epistemologi Burhani}

Al-Burhan dalam bahasa Arab berarti argument yang clear dan distinc. Dalam pengertian logika, al-burhan adalah aktivitas fikir yang menetapkan kebenaran sesuatu melalui penalaran dengan mengkaitkan pada pengetahuan yang bukti-buktinya mendahului kebenaran. Sedangkan dalam pengertian umum, al-burhan berarti aktivitas fikir untuk menetapkan kebenaran sesuatu (Muhammad 'Abid al-Jabiri, 1993. AlJabiri menggunakan burhani sebagai sebutan terhadap sistem pengetahuan yang berbeda dengan metode pemikiran tertentu dan memiliki world view tersendiri, yang tidak bergantung pada hegemoni sistem pengetahuan lain.

Burhani mengandalkan kekuatan indera, pengalaman, dan akal dalam mencapai kebenaran. Metode burhani tersebut dapat diterapkan jika memenuhi beberapa tahap: pertama, tahap pembuatan pengertian yang mencakup jenis, nau', dan fashl. Kedua, tahap pembuatan kalimat. Ketiga, tahap pembuatan silogisme. Silogisme adalah cara berargumen dengan dua premis dan satu kesimpulan. Oleh karena itu, silogisme harus terdiri dari tiga hal, yaitu: (1) dua premis yang saling berhubungan, (2) premis pertama disebut premis mayor dan premis yang kedua disebut premis minor, dan (3) premis penengah yang merupakan kesimpulan.

Ketiga kecenderungan epistemologis Islam ini, secara teologis 
mendapatkan justifikasi dari al-Qur'an.

Dalam al-Qur'an banyak ditemukan ayatayat yang berbicara tentang pengetahuan yang bersumber pada rasionalitas. Perintah untuk menggunakan akal dengan berbagai macam bentuk kalimat dan ungkapan merupakan suatu indikasi yang jelas untuk hal ini. Akan tetapi, meskipun demikian, tidak sedikit pula paparan ayat-ayat yang mengungkapkan tentang pengetahuan yang bersumber pada intuisi (hati atau perasaan) terdalam.

Berangkat dari Hellenisme Yunani yang spekulatif-kontemplatif, para sarjana muslim pada masa kejayaannya leluasa menyerap, kemudian memodifikasi menjadi tradisi filsafat sains yang berangkat dari postulatpostulat al-Qur'an dengan mengetengahkan tradisi berfikir empirikaleksperimental. Usaha tersebut dilakukan dengan mendayagunakan perangkatperangkat intelektual sebagai jalan mencari jawaban tentang hakikat realitas, baik yang nyata (fisis) maupun yang gaib (metafisis). Dari revolusi filsafat di tangan kaum muslimin ini, lahirlah konsep ilmu atau sains yang tegak di atas postulat-postulat Qur'ani (Syamsul Arifin dkk, 1996).

\section{Epistemologi Hukum Islam :}

\section{Antara Teks, Moral dan Akal}

Mahmud Dhaoudi, pakar sosiologi dari Universitas Tunisia, mengkritik pandangan mazhab positivis-empirik. Ia menegaskan bahwa ilmu pengetahuan positivis modern dirasakan tidak menyenangkan dan tidak memadai untuk memecahkan masalah-masalah moral kemasyarakatan dan isu-isu nilai yang tidak bias diukur oleh standar obyektif. Konsekuensinya, intervensi dari wahyu agama dengan adanya pengetahuan absolut berfungsi sebagai pelengkap dari pengetahuan yang dibuat oleh manusia, yang serba terbatas ruang lingkupnya (Jawahir Thontowi, 2002: 140).

Dalam konteks inilah hukum Islam berpijak. Hal ini didasarkan pada alasan berikut ini: Pertama, dalam epistemologi bayani, segenap aktivitas didominasi oleh otoritas teks (wahyu) sebagai sumber utama kebenaran. Sedangkan porsi untuk akal sebagaimana diungkapkan oleh Muhyar Fanani, hanya sekitar + 0-12,5 persen (Muhyar Fanani,, 1999). Penggunaan yang terlalu dominan terhadap epistemologi ini dianggap telah menimbulkan stagnasi dalam kehidupan beragama, karena ketidakmampuannya merespon perkembangan zaman, padahal permasalahan - permasalahan yang dihadapi umat manusia, khususnya umat 
Islam semakin kompleks dan beragam. Metode kasyf dalam kritik epistemologi, bukanlah suatu pola yang berada di atas akal, seperti yang diklaim irfaniyyun. Pendekatannya yang supra-rasional, menafikan kritik atas nalar, serta pijakannya pada logika paradoksal yang segalanya bisa diciptakan tanpa harus berkaitan dengan sebab-sebab yang mendahuluinya, akan mengakibatkan epistemologi ini kehilangan dimensi kritis dan terjebak pada nuansa magis yang berandil besar pada kemunduran pola fikir manusia (Anom S. Putra dkk,, 1999).

Epistemologi burhani berusaha memaksimalkan akal dan menempatkannya sejajar dengan teks suci dalam mendapatkan ilmu pengetahuan. Dalam epistemologi burhani ini, penggunaan rasionalitas tidak terhenti hanya sebatas rasio belaka, tetapi melibatkan pendekatan empiris sebagai kunci utama untuk mendapatkan ilmu pengetahuan, sebagaimana banyak dipraktekkan oleh para ilmuan Barat. Dengan demikian, perpaduan antara fikiran yang brilian yang dipandu dengan hati yang jernih, akan menjadikan iptek, termasuk di dalamnya ilmu hukum, yang dimunculkan kelak tetap terarah tanpa menimbulkan dehumanisasi yang menyebabkan manusia teralienasi (terasing) dari lingkungannya.

Kegersangan yang dirasakan oleh manusia modern ini terjadi karena iptek yang mereka munculkan hanya berdasarkan atas rasionalitas belaka, dan menafikan hati atau perasaan yang mereka miliki. Mereka menuhankan iptek di atas segala-galanya. Sedangkan potensi rasa (jiwa) mereka abaikan, sehingga mereka merasa ada yang hilang dalam diri mereka. Keseimbangan antara fikiran (fikr) dan rasa (dzikr) ini menjadi penting karena secanggih apapun manusia, ia tidak akan dapat menciptakan sesuatu. Keduanya, fikr dan dzikr adalah pilar peradaban yang tahan bantingan dalam situasi dan kondisi seperti apapun. Keduanya adalah perwujudan iman seorang muslim. Umat yang berpegang teguh kepada dua pilar ini disebut alQur'an sebagai ulul albab, ulul abshar. Mereka, di samping mampu mengintegrasikan kekuatan fikr dan $d z i k r$, juga mampu mengembangkan kearifan yang menurut al-Qur'an dinilai sebagai khairan katsiran. Kedua, dalam konteks hukum Islam, al-Jabiri memasukkan teologi dan fiqh dalam epistemologi bayani.

Menurut penulis, sangat tidak memadai bila hukum Islam hanya dimasukkan pada epistemologi bayani 
sebagaimana yang dipahami al-Jabiri. Benar, fiqh oleh al-Jabiri dikategorikan dalam epistemologi bayani, namun fiqh jelas berbeda dengan epistemologi hukum Islam. Yang pertama adalah produk, sementara yang kedua adalah kaidah-kaidah yang dipergunakan dalam menentukan produk tersebut. Dengan demikian, keduanya tidak mungkin disamakan atau dianggap sama.

Keduanya jelas berbeda. Akan tetapi memiliki hubungan yang sangat erat. Dimasukkan dalam kategori epistemologi 'irfani, hukum Islam juga sangat susah. Hal ini terjadi karena hukum Islam tidak melulu berurusan dan bersumber dari hal-hal yang bersifat wujdani dan hati nurani manusia. Hukum Islam sangat erat hubungannya dengan interaksi yang bersifat sirkular, artinya kajian hukum Islam mencakup hubungan antara manusia dengan Tuhannya, hubungan manusia dengan dirinya sendiri, dan hubungan antara manusia dengan yang lainnya. Apabila dimasukkan dalam epistemologi burhani juga dianggap kurang memadai. Sebagaimana dalam pemahaman al-Jabiri tentang epistemologi burhani ini, yang dijadikan sebagai sumber adalah realitas alam, sosial, dan humanitas. Metode yang dapat dikembangkan adalah abstraksi dan analisis.
Pendekatan yang sering digunakan adalah filosofis dan saintifik. Hukum Islam dalam hubungannya dengan epistemologi ini, secara nyata memang tidak dapat dipisahkan karena memiliki sumber yang sama. Akan tetapi sekali lagi hukum Islam tidak hanya berbicara dan bersumber dari realitas alam, sosial dan humanitas belaka. Hukum Islam tidak akan mampu melepaskan diri dari ayat-ayat al-Qur'an dan pengetahuan Tuhan yang diperoleh melalui wujdan dan hati nurani manusia.

Dengan demikian kurang pas bila hanya dimasukkan dalam epistemologi ini. Barangkali hukum Islam cukup layak untuk dijadikan sebagai sebuah epistemologi tersendiri yang mencakup ketiga epistemologi al-Jabiri di atas. Dalam hal ini bisa disebut dengan epistemologi jama'i atau epistemologi komprehensif, artinya hukum Islam merupakan sebuah epistemologi tersendiri yang disebut dengan epistemologi jama'i atau epistemologi komprehensif. Ketiga, dalam ajaran Islam, pembentukan moralitas masyarakat terjabar secara komprehensif dan sistematis. Manusia memang hidup dalam tatanan yang empiris dan berkembang, tetapi tidak mungkin bisa terlepas dari kategori jasmani dan rohani. Maka pembentukan tatanan sosial atau 
masyarakat (hukum), mestinya juga tidak terlepas dari moralitas agama. Hal ini disebabkan karena hukum, moralitas, dan agama harus dipahami sebagai tiga hal yang terkait satu sama lain.

\section{KESIMPULAN}

Dari berbagai paparan di atas dapat disimpulkan, bahwa tuntutan era postpositivisme yang telah melahirkan pandangan bahwa hukum tidak hanya dimaknai sebagai realitas sosial yang empirik an sich tetapi juga realitas metafisik yang tidak dapat dijangkau oleh panca indera, ternyata sejalan dengan bangunan pemikiran hukum Islam. Hal ini setidaknya didasarkan pada alasan-alasan berikut: (1) Islam menuntut perpaduan antara fikiran yang brilian yang dipandu dengan hati yang jernih, karena kepatutan berfikir selalu disertai dengan jiwa yang bersih dan balancing dengan perbuatan(2) keterbatasan epistemologi dalam pengembangan pemikiran hukum Islam, meniscayakan adanya keterpaduan epistemologi tersebut secara komprehensif, moralitas agama sangat berperan dalam membentuk tatanan sosial atau masyarakat (hukum). Karena dengan adanya moralitas yang baik dari agama, akan membawa pemahaman yang mendalam dan lebih cerah.

\section{DAFTAR PUSTAKA}

Arifin, Syamsul dkk. 1996. Spritualisasi Islam dan Peradaban Masa Depan, Yogyakarta: SIPRESS.

Douzinas, Costaz. et. al. 1991. Postmodern Jurisprudence: The Law of Text in The Texts of Law, Routledge: London, 1991.

Fanani, Muhyar. 1999. Epistemologi Ilmu Ushul al-Fiqh: Sebuah Refleksi Filosofis Perbandingan antara al-Ghazali dan al-Syatibi, Tesis Pascasarjana IAIN Sunan Kalijaga, Yogyakarta.

Harre, R. 1978. The Philosophies of Science: An Introductory Survey, London: Oxford University Press.

Al-Jabiri, Muhammad 'Abid. 1991. Takwin al-'Aql al-'Arabi, Casablanca : Al-Markaz alTsaqafi al-Arabi.

1993.

Bunyah al-'Aql al-'Arabi: Dirasah Tahliliyah Naqdiyyah li Nuzhum al-Ma'rifah fi alTsaqafah al-Arabiyah, Casablanca: Al-Markaz alTsaqafi al-Arabi, 2000. Post Tradisionalisme Islam, Terj. Ahmad Baso, Yogyakarta: LKiS, 2000.

Kartanegara, Mulyadi. 2000. "Membangun Kerangka Ilmu: Perspektif Filosofis”, dalam Kamaruddin Hidayat dan Hendro Prasetyo, Problem dan Prospek IAIN: Antologi Pendidikan Tinggi Islam, Jakarta: Departemen Agama.

Mahfud, Moh. 1999. "Politik Hukum: Perbedaan Konsepsi antara Hukum Barat dan Hukum Islam" dalam al-Jami'ah IAIN Sunan Kalijaga Yogyakarta No. 63/I. 
Putra, Anom S. Dkk. 1999. "Revolusi Nalar Islami: Menangguhkan Teks, Mencuri Subyek”, Gerbang: Jurnal Pemikiran Agama dan Demokrasi, Edisi 02, Th. II.

Shah, 'Abied, M. Aunul dan Sulaiman Mappiase. 2001. "Kritik Akal Arab: Pendekatan Epistemologis terhadap Trilogi Kritik al-Jabiri” dalam M. Aunul Abied Shah, Islam Garda Depan, Bandung: Mizan.

Thontowi, Jawahir. 2002. Islam, Politik, dan Hukum:Esai-esai Ilmiah untuk Pembauran, Yogyakarta: Madyan Press. 